\title{
Polysèmes
}

Revue d'études intertextuelles et intermédiales

$15 \mid 2016$

L'or et l'art

\section{Fantasied images of women: representations of myths of the golden apples in "classic" Victorian paintings}

Images féminines et fantasmes : représentations des mythes grecs des pommes

d'or dans la peinture victorienne "classique»

\section{Anne-Florence Gillard-Estrada}

\section{OpenEdition}

\section{Journals}

\section{Electronic version}

URL: http://journals.openedition.org/polysemes/860

DOI: $10.4000 /$ polysemes.860

ISSN: 2496-4212

\section{Publisher}

SAIT

\section{Electronic reference}

Anne-Florence Gillard-Estrada, « Fantasied images of women: representations of myths of the golden apples in "classic" Victorian paintings », Polysèmes [Online], 15 | 2016, Online since 15 May 2016 , connection on 19 April 2019. URL : http://journals.openedition.org/polysemes/860 ; DOI : 10.4000/ polysemes.860

This text was automatically generated on 19 April 2019

Polysèmes 


\title{
Fantasied images of women: representations of myths of the golden apples in "classic" Victorian paintings
}

Images féminines et fantasmes : représentations des mythes grecs des pommes d'or dans la peinture victorienne " classique»

\author{
Anne-Florence Gillard-Estrada
}

1 This article proposes to examine the treatment of Greek myths of the golden apples in paintings by late-Victorian artists then categorized in contemporary reception as "classical" or "classic". These terms recur in many reviews published in periodicals. ${ }^{1}$ The artists concerned were trained in the academic and neoclassical Continental tradition, and they turned to Antiquity for their forms and subjects. They looked back to Greece both as an intellectual ideal and a plastic model, which, to them, was best exemplified in Greek sculpture. Art critics often described the "classical" types of beauty they devised as expressing noble grandeur and pure perfection. Indeed, many painters-and the critics who were favourable to them-adhered to an academic tradition that posited the intellectual and formal supremacy of Greek sculpture.

Some of these painters have also been related to Aestheticism because of their decorative handling of colour and their formalist approach to painting-one that was based on the primacy of line and colour for their own sake. ${ }^{2}$ The art of Frederic Leighton (1830-1896) is paradigmatic of the synthesis of these two artistic and aesthetic tendencies. In a letter of 1873 , he insists on the central role of "classic subjects", which to him are "vehicles [...] of abstract form" (Carr 98), thereby establishing a link between the fundamentals of classicism and the principles of Aestheticism. Many of his canvases thus emphasize form and colour at the expense of meaning. And yet his predilection for mythological themes shows that subject does play a significant role in his works.

Gold as a pigment is lavishly used in these eclectic pictorial trends. It is employed as pure colour, with backgrounds or scenes glimmering with a golden lustre, as in a number of 
Aesthetic paintings by Leighton. In such cases, its function is wholly decorative, but it has a further value for Aesthetic artists: gold is the colour of religious art par excellence and so it participates in the elevation of beauty-mostly the beauty of the body-to a cult. But many "classical paintings" also treat myths in which this precious material features prominently. In particular, the myth of the golden apples is often associated to female beauty. In Greek mythology, the golden apples are divine fruits that confer immortality or fecundity. They function as tokens of desire and sensual bliss, especially when they are given by Aphrodite. In Victorian painting, the golden apples too are invested with much symbolic significance. They allow painters to represent eroticized subjects, such as the female nude in the Judgment of Paris. ${ }^{3}$ The myths of Atalanta's race or of the garden of the Hesperides are particularly present in many canvases, either directly or indirectly. In these cases, the symbolism of the golden apples conflates mythical, gendered and political dimensions, especially because they are associated with woman. They come to articulate fantasies and anxieties that are both idiosyncratic and contextualized.

Georges Didi-Huberman's study of images is particularly helpful in exploring such tensions. One of his contentions about iconology is that it posits too close a relation between form and intellectual discourse. This relational process he defines as "metaphor", a process in which the sign can only be legible within the exclusive system of iconology. To him, visual representation has an underside that is not sufficiently taken into account (Didi-Huberman 1990) and this mostly because of the humanist primacy of idea over the body. In such exclusive reading, the images are reduced to paradigms and the forms are even contradicted by the idealized content that is ascribed to them. Such reading of the images equates the body with a metaphor, with an abstract idea or with a simple iconographical theme. Hence, Didi-Huberman encourages a reading which "embodies" or "incarnates" the human form, and which explores its "symptoms". Forms should not be exclusively studied as part of a dynamic process in which the visible bodies are associated to the ideas they are supposed to signify, as in the allegorical process; they have to be envisaged in a process called "metamorphosis", which implies that the human form, or the body, should be related to other forms (Didi-Huberman 2007, 26-28).

5 This is especially the case for the Victorian academic "classical" painters but also for Aesthetic artists. Greek forms were indeed fundamentally metaphoric as they were associated to an ideal and to the notion of pure form. This was a staple of the artists' rhetoric, which was often taken up in contemporary art criticism. Besides, many of these artists revered and emulated Renaissance artworks; they were engaged in the widespread circulation of forms that has always characterized Western art-mostly the classical forms of Greco-Roman art as they were mediated by Renaissance art. In the discourses of the "classical" artists and of many reviewers, the human form is associated to an idealized form, which precisely corresponds to the metaphorical process Didi-Huberman describes. But the human form in their canvases is also counteracted by the "movements" or "symptoms" which agitate the bodies. This, for Didi-Huberman, is the metamorphic event par excellence.

6 A perfect example of such process is the way the mythical golden apples are represented in these "classical" paintings. Both the apples and the human forms articulate desires and psychosexual concerns. Interestingly, the critical reception of these works contains nearverbalizations of the tensions at stake in the images. Despite the academic aesthetics that looks back to "classic" models for idealized and serene representations of the body, and despite the Aesthetic emphasis on form-the harmonious play of colours and lines-at the 
expense of subject, the body emerges as the site of complex impulses. The golden apples shape up fantasies or anxieties linked to the female body, now connoting desire but also male conquest, now female languor and self-absorption. They function as the node of male domination and of the male gaze on female sexuality.

In the 1870s Edward Poynter (1836-1919) worked on four large commissioned canvases, now lost, on the mythical subjects of Atalanta, Nausicaa and Andromeda, which he first exhibited at the Royal Academy. Atalanta's Race (1876) ${ }^{4}$ only survives through photographs, ${ }^{5}$ engravings, ${ }^{6}$ magazine illustrations and preparatory drawings (Bell, plates 12, 14 and 15). ${ }^{7}$ Various Greek or Latin sources present Atalanta as the beautiful daughter of a prince from Arcadia or Boeotia who wanted a boy and so exposed her in the wilderness. ${ }^{8}$ She is raised by animals and becomes a huntress and a swift runner who vows to remain a virgin. When she is later reunited to her father, he decides to marry her, but she only accepts on condition that her husband-to-be should beat her in a foot race. All her suitors lose and are put to death, except Milanion (or Melanion, also called Hippomenes), who falls in love with her and begs Aphrodite for help. The goddess of love gives him three golden apples, which he drops during the race; Atalanta slows down to retrieve the precious fruits and Milanion wins. In Ovid's text, Atalanta experiences some confusion when she sees this beautiful man, whom she suddenly feels attracted to. According to some versions of the myth, their desire for each other is so strong that they sacrilegiously make love in the temple of Cybele, who turns them into lions; or else, they are metamorphosed because Milanion has forgotten to show gratitude to Aphrodite.

8 Close to Poynter, this episode appears in two texts, Atalanta in Calydon (1865) by A.C. Swinburne and "Atalanta's Defeat" by William Morris (The Earthly Paradise, 1868-70). Poynter was also certainly aware of the numerous representations of the myth by the Great Masters. But he differs from most of them as he chooses to set the race in a Greek city instead of the more traditional forest. The two figures occupy the centre of the picture plane: Atalanta has stopped and reaches for a golden apple, holding another one in her hand; to her left, Milanion rushes, glancing at her and holding the last apple. In the background, various Greek spectators are assembled along marble walls that delimit the track and separate the canvas into two horizontal planes. The eye is thus led on, slightly obliquely, towards the end of the racetrack to the right. The finishing line is indicated by a tall pillar that echoes other vertical lines, such as the pilasters and the fluted Doric columns. The figures are interspersed somewhat rhythmically in a mainly linear composition, which is also relieved by curving draperies.

9 The apples are the pretexts for an antagonistic representation of masculinity and femininity. Poynter's depiction of the two nude male figures-Milanion and the man immediately to his left-are modelled on the muscular male bodies found in Greek sculpture and in Michelangelo's pictorial and sculptural works. Kestner pertinently suggests that Poynter makes "a celebration of muscular Christianity in pagan guise", which testifies to his "belief in the study of anatomy and the magnificence of the human form" (Kestner 1999, 217-218; 210-211). What's more, the painting emphasizes the athletic strength of the male runner while carefully ignoring the vigour of the mythical woman hunter. The treatment of their respective bodies is highly contrasted. The man wears a thin drapery that enhances his victorious nudity; his back is turned to us and his buttocks are visible. A strip of drapery oddly juts out and his legs are drawn in full momentum. The spectator can therefore contemplate his well-built figure. The woman, on the other hand, is enmeshed in complicated draperies that literally enclose her within a womblike 
whirlpool of cloth; because she stoops, her head is placed at the centre of this vortex. A few selected parts of her body are revealed-her smooth arms, legs and breasts-so that far from being athletic, the female body is eroticized. Although the man's legs visually echo the woman's legs and extended arm, a contrast is established between his full stride and her closed legs.

Poynter's Atalanta no longer evokes female strength or hunting skills, unlike some representations of that mythic figure on Greek vases ${ }^{9}$ or statues. ${ }^{10}$ Poynter has erased anything that could be construed as masculine, thus providing a particularly gendered representation of the woman. The mythical Atalanta lives free in the wild forests, but her defeat against a sly suitor leads to her reinsertion within the polis and the sphere of womanhood constructed by patriarchal society. ${ }^{11}$ Poynter's studies for the nude figure of Atalanta and the drapery show that he originally devised her as a dynamic figure: her left leg is extended, like Milanion's, and the folds of the drapery indicate speed and movement; she seems to be floating above the ground (Bell, plates 12 and 14). But she is much more static in the finished canvas. Heroism and vigour have been reassigned to the male body. It is lithe and muscular, but also active and free, whereas the woman's smooth and graceful body bends down and is constrained by the knot of drapery.

Expurgated too are the connotations of desire associated with the golden apples. In Guido Reni's Atalanta and Hippomenes ${ }^{12}$ (1615-1618), Atalanta's movement towards the apples is matched by the man's haughty attitude: he has thrown the apple and his arm is still extended, but this gesture also expresses his pride at having conquered a much-desired prize. Atalanta holds an apple against her naked abdomen, which signifies the sexual dimension of the race. Visually, the two figures are united by the flow of draperies as well as by their postures: their right arms are extended, their left arms placed against their flanks, and their legs cross. Power and desire intermingle in this scene of sexual conquest. The golden apples function as signs of the man's domination over the woman and as symbols of sexual experience. Poynter's figures, on the other hand, are monolithic ciphers of masculine vigour and feminine receptacle. As for the golden apples-gifts from the goddess of love-, they now appear as nuggets which are invested with a mercantile value. The woman who covets them is deprived of any emotions especially because her face is turned downward, and the man seems only bent on winning. The Greek legend is about sexual desire, which the golden apples come to symbolize, but Poynter's treatment privileges gendered competition, female venality and male aptitude. For in the Victorian context, the mythical female-male contest raises gendered anxieties, which are resolved through the containment of the woman. 


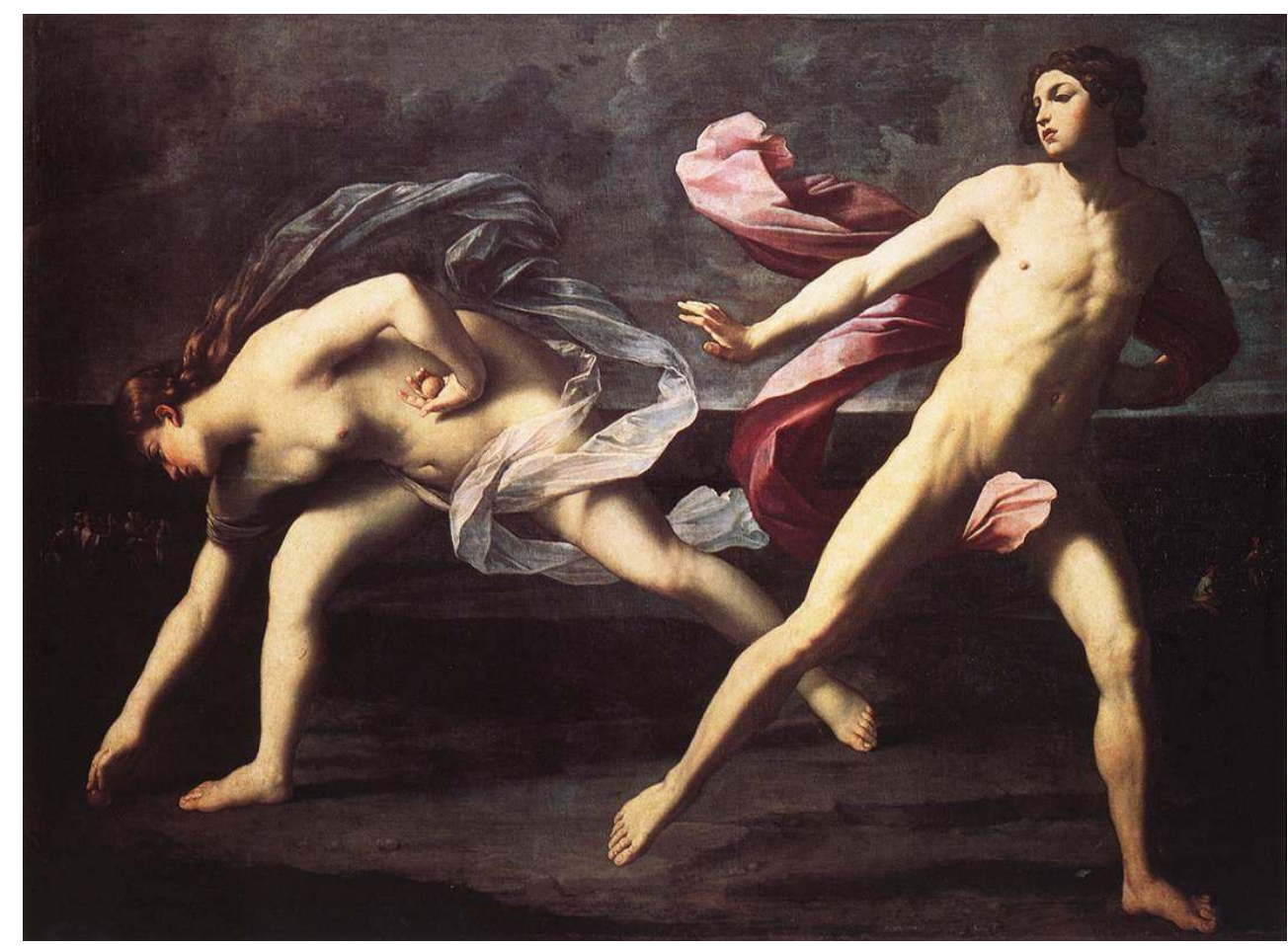

Guido Reni, Atalanta and Hippomenes (c. 1615-18), oil on canvas, 206×297cm, Museo Nacional del Prado, Madrid, Creative Commons

12 A number of contemporary reviewers were alert to that ideological dimension. For Henry Blackburn, Atalanta "stoop[s] to be conquered" and the myth "is made the vehicle for a painting of great interest and instruction" (Blackburn 61). In fact, the didactic lesson he seems to discern in the painting has to do with the role assigned to woman in a context of Victorian social evolutions. Revealingly, Punch published a parody by George Du Maurier that transposes the mythical quest into a contemporary issue: women's social and professional conquest for medical patients. ${ }^{13}$ The cartoon highlights-and probably endorses-the defeat of a female doctor, whose pretensions for professional autonomy end with matrimony. For the golden apples are tellingly replaced by a wedding ring.

It was the emotionlessness of Poynter's figures which the critic Harry Quilter particularly disliked. Indeed, he sees "[n]one of the intense emotion of the man who was running for his life and his bride, or of the woman whose fate hung upon the result of her exertions" (Quilter 99). That is, there is no sign of the man's fear of death, of his desire for the woman, or of the woman's anguish at the loss of her unmarried status. Consequently, the figures are mere technical achievements. The issue of the absence of emotion is also raised in Margaret Oliphant's review: in fact, the return to classical antiquity entails the absence of emotion. At a time when contemporary reception of such paintings of Antiquity was divided between the neo-Winckelmannian construction of an ideal of beauty and repose, and the acknowledgment of the more complex aspects of Greek art and culture, Oliphant adheres to the idealized Greek model: "a story is told, and dramatic action, of what ought to be almost a violent kind, is brought in", but the absence of "any moral expression in the countenances of these two strange impersonations of Greek feeling [...] is in perfect accordance with the subject". Still, she regrets the lack of coherence in Poynter's "rendering of the Greek". Such aesthetics differs from a "modern idea of the theme", which "would demand such eager passion in the lover, and such fierce union of virgin pride and almost-cruelty with the curiosity and covetousness that could 
be tempted by that golden toy [...] as would task to the utmost the resources of painting". The Greek protagonists have to be emotionless because the "simple and primitive principles of dramatic action at that early period do not require any analysis of feeling, still less any damping influence of reflection". However, she notes a "contrast" between the opportune lack of expression on the two protagonists' faces and the "passionate interest" or "excitement" of the spectators in the background; the spectators, therefore, "are of the modern world" and are "a group [...] of hot Italians", instead of "a statuesque marble public, fit background for the classic strife" (Oliphant 762-763). To her great dismay, excitement has been displaced to the borders. This perhaps explains her silence about the golden apples-exactly as their value as tokens of desire is forgotten in the painting itself. The sensual dimension of the myth is evaded both in the work and in its appraisals.

Frederic Leighton was another painter who represented the myth of the golden apples. But he also makes an indirect allusion to it in his painting Greek Girls Picking up Pebbles by the Sea (1871). Though not an illustration of this subject, the reutilization of Guido Reni's painting of Atalanta and Hippomenes links it to the myth. At stake too here is a circulation of bodily forms that may be seen as a dissemination of "symptoms", to take up Didi-Huberman's term. Consequently, this painting of Greek women turns into a puzzling image of female psychosexual interiority.

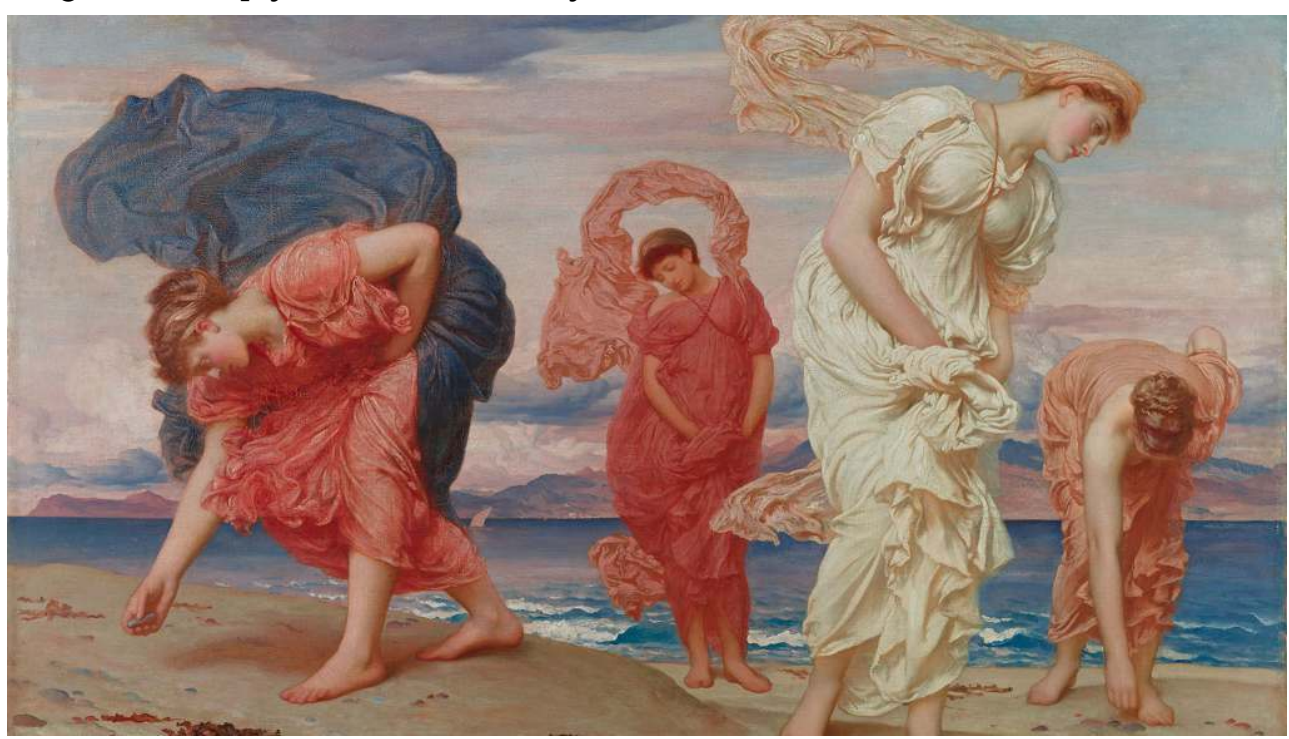

Frederic Leighton, Greek Girls Picking up Pebbles by the Sea (1871), oil on canvas, 84x129.5cm, private collection, Creative Commons

For Elizabeth Prettejohn, this canvas corresponds to Leighton's most Aesthetic and formalist phase, along with Summer Moon (1872), Summer Slumber (circa 1894), or Flaming June (1895) (Prettejohn 1999, 89-110; 2007, 112-116). It differs from the classical and mythological subjects he regularly exhibited at the Royal Academy. Besides, the representation of women walking along the seashore echoes other contemporary Aesthetic canvases, such as Shells and Sea Gulls (1870-1871) by Albert Moore and Symphony in Blue and Pink and Variations in Blue and Green (circa 1868) by James Abbott McNeill Whistler. All three painters derived their compositions from Renaissance pictorial variations on the mythological subject of the birth of Venus, which they transposed into Aestheticized feminine figures clad in classic draperies animated by the wind. 
16 flesh pinks, russet oranges, and creamy whites; it is a rhythmic arrangement of women conceived separately but symmetrically. The four figures seem related to each other not by psychological or narrative associations but by the curving patterns and the vertical lines which they form as they stand out against the horizontal plane of the sea and beach in the background. This induces Christopher Newall to call it a "seminal work of the Aesthetic Movement", whose "subject requires no elucidation" as it is "a decorative scheme in which the standing and bending figures provide an abstract rhythm of shapes and colours"; it is "an exploration of what Leighton considered to be ideal beauty-the draped female form in a timeless landscape setting" (Newall 74). Likewise, Stephen Jones stresses the absence of narrative content in a painting which is not hung "on the peg of any subject", either literary or mythological; he affirms that "[t]here is no emotion to which the draperies must conform in character, nor any need to tie the picture down to reality, so the eye enjoys the colours and forms simply for what they are-beauty as an end in itself" (Jones 169-170).

The picture displays the typically Aesthetic synthesis of Antiquity, Renaissance, contemporary Aestheticism, and also of landscape painting. Leighton worked up the background from sketches of the coast of Asia Minor he made in 1867. Rosemary Barrow has shown that the wind-blown drapery is modelled on fifth-century Greek sculpture: the himation blowing above the women's head recalls the two Nikai of a decorated parapet in the Temple of Athena Nike ${ }^{14}$ (Barrow 1999, 51-56); the windswept veils and the transparent, billowing draperies, which cling to the figures' bodies, are copied from the Nereids acquired by the British Museum in $1843 .{ }^{15}$ The two standing figures topped by arching loops of drapery also conform to the Italian Renaissance type which Aby Warburg, in his dissertation on Botticelli (1889), designates as the nympha-that is, a beautiful female nymph whose draperies reveal the shape of her body and whose hair is agitated by breezes. To Warburg, this figure provided Renaissance painters with a model that enabled them to represent pagan energy in religious art (Warburg 49ff). ${ }^{16}$ Furthermore, Warburg conceptualizes the notion of the Pathosformeln, or forms of pathos -that is, the signs of passion or of affects-, which Didi-Huberman uses to discuss Botticelli's Birth of Venus: although the goddess seems impassive, forms of pathos are displaced onto other elements on the fringes of the image, such as the waves (DidiHuberman 2002). Likewise, Leighton's figures look emotionless and yet the agitated draperies function as displaced forms of pathos, or of emotion. Besides, a whole chain of associations opens up because of the composition and the pose of the figure on the left, which are clearly derived from Guido Reni's painting. ${ }^{17}$ Not only is the mythological subject of Atalanta conjured up, but the pebbles that give the painting its title also function as imaginative transpositions of the golden apples. All in all, reading that picture solely as a paradigm of pure Aestheticism overshadows the connotations suggested by the formal echoes.

What is actually at stake in this canvas is the body and sexuality. In Reni's picture, the figures' thin and translucent draperies-of a warm pink colour for the man and of a cold blue for the woman-flow in symmetrical arabesques that entwine their bodies. Leighton aims at distinctive effects: he has removed the man and describes four women; and the erotic caress of the draperies has given way to complicated knots and billowing folds. Leighton was attracted to Hegel's ideas that drapery, unlike modern costume, could best express the inner life of the subject (Prettejohn 2007, 138ff). Here, he displaces the signs 
of emotion-or, the symptoms of pathos-onto the almost liquid draperies, which disclose more than they hide the women's naked bodies. They have a life of their own and function as signs of an agitated self. Whirling up and forming arches, they seem to flow away from the women's bodies like centripetal and centrifugal energies, only to be absorbed back within the sterile vortexes that they hold close to their wombs. They are non-mimetic iconic signs, which are charged with a strong affective potential. Besides, the bodies are bent and isolated; the women are engrossed in some melancholy reflexion. In his canvas, Guido Reni uses a number of elements, among others the golden apples, to represent the man's imminent possession of the woman and the end of Atalanta's maidenhood and autonomy. Here, the cold pebbles the women pick up symbolise a kind of withdrawing into themselves. The golden tokens of desire are transposed into sterile and dull stones, and the women are left to their isolated selves. Incidentally, Leighton both uses and departs from another source-Joshua Reynolds's Three Ladies Adorning a Term of Hymen (1773). ${ }^{18}$ The composition and decorative treatment of the curving lines and gradated colours are quite similar. However, the colours in Reynolds's canvas symbolically connote the different social and sexual status of the Montgomery sisters, from maiden to fiancée and then to bride; but Leighton's treatment of the colours is nostalgic and there is no suggestion of any nuptials to come.

F.G. Stephens's review for the Athenaeum reflects the ambivalence of the image. He exonerates Leighton's treatment from any sensuality while indulging in the figures' voluptuous dimension: they are "of almost exhaustless grace, and wealth of beauty in design and colour"; there is much "loveliness [...] in the stooping forms of the damsels, whose draperies a boisterous wind tosses without betraying"; and so the "subject [is] fitted to show the nobility of the artist's power", mostly because Leighton, unlike other painters, "could avoid at least a suspicion of desire to hint, however delicately [...] at the personal charms of the girls, who are thus beset by the breezes of the sea". However, he considers that "[i]t would be hard, in fact, for most designers to avoid making, so to say, a note that they had suppressed something of the sensuous, or rather luxurious, order, in treating such a subject as this" (Stephens 1871, 532). Stephens's wording is rather convoluted, which perhaps is due to the tension that besets the idealizing tendency: indeed, it cannot totally prevent the return of what, precisely, has to be "suppressed". In that view, the absent, luscious golden apples of the myth may also function as a repressed element in a general metaphorical circulation of forms and motifs. They have become here unseen pebbles, that is, lustreless, unfruitful and hard stones, which no longer bring the promise of bliss.

Leighton tackled the myth of the golden apples more directly in The Garden of the Hesperides (c. 1892). The Hesperides are nymphs of the evening and of the golden light of sunset, who were entrusted by Hera to tend her garden and her golden apples. In some versions of the myth, Hera suspected them of occasionally plucking some of the precious apples and so she placed a dragon or a serpent, Ladon, to watch them. ${ }^{19}$ Leighton represents the three Hesperides leaning against the tree and forming an interlocking group with the serpent. 


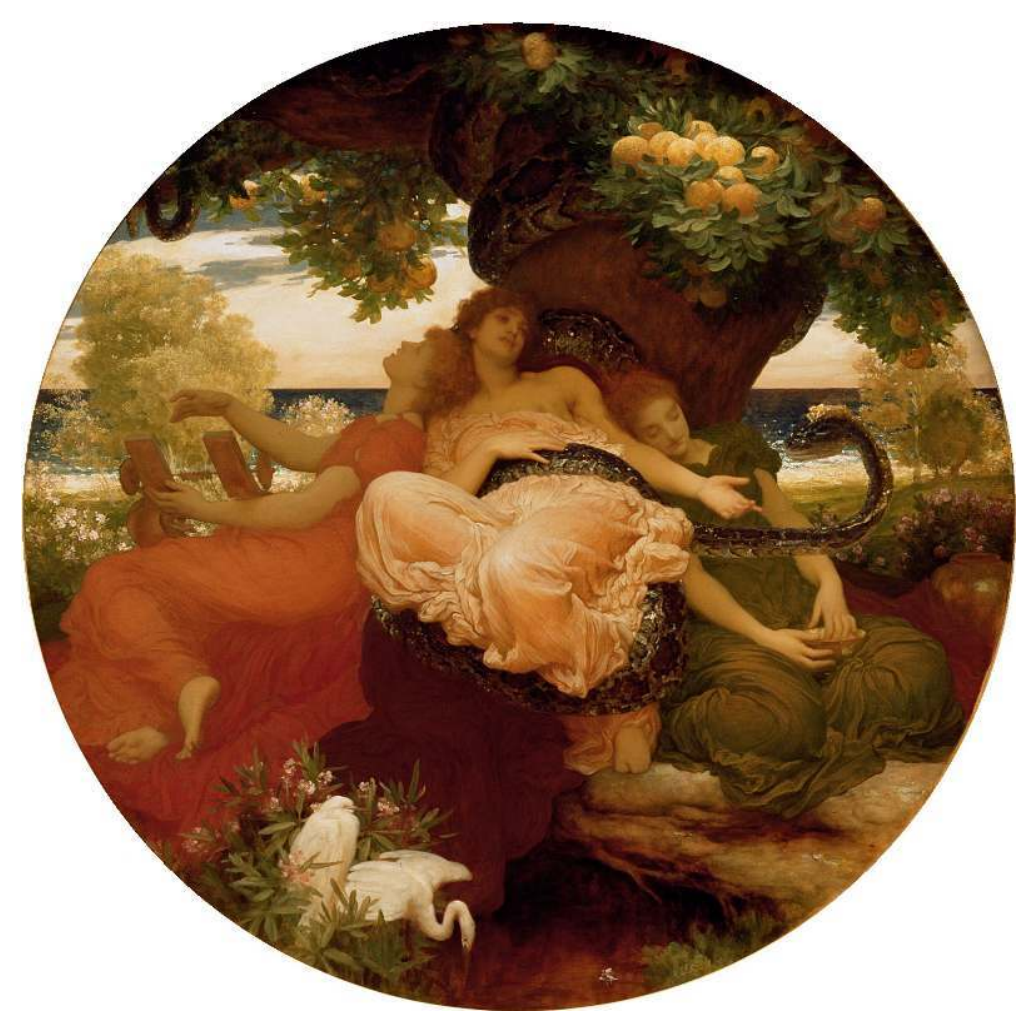

Frederic Leighton, The Garden of the Hesperides (c. 1892), oil on canvas, diameter 169cm, Lady Lever Art Gallery, Creative Commons

Leighton differs from other contemporary representations of the theme. In The Garden of the Hesperides of $1870,{ }^{20}$ by Edward Burne-Jones (1833-1898), the three girls dance around the tree, holding their hands. It is a variation on the motif of the archaic round dance. The mood is one of sensuality but also of melancholy. Burne-Jones also represented the apples in a tapestry placed in the background of his Laus Veneris (1873-1875, Laing Art Gallery, Newcastle-upon-Tyne): a sad-looking Venus is seated on her chariot, surrounded by draped figures that eagerly present her with golden apples. It is another tribute to beauty and sensuality; but instead of evoking sensual bliss, the golden apples are associated with languor, sadness and exhaustion. W.H. Hunt too alludes to the myth in a tapestry featuring in his Lady of Shallot of 1886-1905 (Wadsworth Atheneum, Hartford, Connecticut). A nude Heracles, whose nimbus relates him to Christ, intrudes into the garden and manfully seizes the apples, while the passive nymphs lie down against the tree.

Leighton's version shows no dramatic action. He has opted for a mood of sensuality and stillness. It is yet another variation on the languorous female type he favoured-a male fantasy of isolated and abandoned women, seized by some peculiar erotic torpor. It is a highly decorative and Aesthetic treatment of the mythical subject, which emphasizes feminine beauty. The three Hesperides are immersed in pure sensory and sensual experience: the girl on the left entrancingly plays on an ancient lyre, which suggests auditory sensations; the golden apples she looks at cravingly conjures up the sense of taste; and the woman on the right indolently touches a bowl, which evokes the sense of touch. The bright oranges, reds, yellows, greens, and browns are harmoniously arranged. The chromatic arrangement obviously is devised to produce Aesthetic effects; but the colours also allude to the cycles of the seasons and enhance sensuousness and sensuality. 
To boot, the woman, in the middle, who was clearly modelled on Dorothy Dene, toys with Ladon in a suggestive manner. The legs of the two women on the right are visual prototypes of the thigh and leg of the figure of Flaming June, ${ }^{21}$ which is a transposition of another Greek myth that associates gold and desire. Indeed, this painting depicts a dozing woman who languidly abandons herself to the golden beams of the sun; the golden light evokes the rain that impregnates Danaë, while her foregrounded thigh is a visual echo of Michelangelo's highly erotic Leda. ${ }^{22}$

Once again, the draperies are animated by some independent dynamics, and they bear no relation to the form underneath. For Barrow, their "mass of folds and counterfolds" is "characteristic of Hellenistic statues" of sleeping figures, which were already characterized by a contrast between the "troubled drapery" and the "placid repose of the sleepers" (Barrow 1999, 54). In Leighton's canvas, the ripples of the three women's wet draperies do not only emphasize their curves but seem to reflect some flowing bodily energy.

The garden suggests a lost Arcadia $^{23}$ but the golden apples and the serpent also evoke the forbidden fruit in the Garden of Eden. The serpent appears as a giver of sexual pleasures to which the compliant girl has languorously succumbed. Leighton could have found representations of Ladon as a snake in various examples of Greek and Roman art. ${ }^{24}$ Yet it also echoes contemporary canvases that feature legendary women erotically playing with phallic-like snakes, such as John Collier's nude Lilith (Atkinson Art Gallery, Southport), which was exhibited the same year. The woman-serpent motif was a staple of many Symbolist works that took up mythological themes in the 1870s. Such representations could also call to mind Gustave Flaubert's very suggestive description of the Carthaginian princess and her snake in Salammbô (1862). For Leighton's vision is undeniably eroticized: the woman's drapery has been slightly pulled down, thus showing one of her breasts, perhaps under the action of the snake's coils. What's more, her skin seems a bit pallid and her eyes are circled with dark tones, as if to point to exhaustion. Incidentally, Kestner mentions that in several preparatory drawings the serpent originally loomed up from under the woman's crotch, but this was probably too blatantly erotic and Leighton modified it (Kestner 1999, 160).

Both the female figures and the golden apples are replete with evocations of juiciness and lushness. Leighton adopts the round format of the Renaissance tondo, which perfectly reflects the sensuous and yet self-sufficient world of the women. It also echoes the circular clusters of the round golden apples. In fact, the motif of the circle proliferates in the canvas, such as the constricting coil of the snake, placed in the centre of the canvas. All these circular shapes reinforce the erotic symbolism. What's more, the woman clad in a green rippling drapery-whose shape evokes sexual configurations-puts her hand into a bowl placed against her crotch, which conjures up the imagery of a receptacle that is associated with the feminine and finds an echo in the snake's circular coil. The girl therefore seems lost in some strange autoerotic daydream. The frame is like a lens through which a voyeuristic beholder-who is clearly conceived as male-is allowed to see this fantasy of female desire and autoeroticism..$^{25}$ There seems to be a progression from the woman on the left who expectantly lifts her head towards the promising apples, to the enervated girl in the middle who desirously eyes the serpent, and finally to the dozing figure on the right, who fingers an empty vessel. The round shapes of the forbidden golden fruits are echoed by the general circularity which encloses the three wan and wearied women. 

circularity is broken up by "crossed lines" that "tell of unseen hazards", that is, of the disruption of cyclical time (Newall 129). Indeed, the round shapes are counterpointed by the triangular masses of bodies and draperies as well as by the diagonal lines of the legs and of the curiously twisted tree. Its red-brown diagonal crosses the canvas and it ends up with a globular mass that melts with the dark pool underneath the tree. This looks like a curious cavity that echoes the snake's constricting spiral around the woman's body. But it is as unfathomable as the women's psyche. Leighton treats the myth of the golden apples as a way of exploring woman's desire, but what surges up is a stereotypical vision of women: they are enclosed within their mysterious psychosexual interiority, and such representation is meant to titillate the male spectator.

Despite its belated choice of a Greek subject, the reception of the canvas was quite positive. Many reviewers stressed its decorative dimension, which consequently tends to elude the eroticism of the subject represented. George Moore describes the picture as a "charming and original [...] piece of decoration" (Moore 835). The anonymous reviewer of The Times estimates that such "scenes of Greek literature and life" require that a painter should "choose the simplest and the most purely decorative subject": this is why this image of "three beautiful maidens grouped round the foot of the orange tree with the mystic serpent twining around and among them" is "very little more than an exquisite study of line and colour, with no more story than is required to give consistency to the composition" ([Anon.] 14). Such commentary is strikingly oblivious to the erotic charge of the canvas.

Claude Phillips, in a review for the Academy, oscillates between laudatory comments and near-verbalizations of its ambiguities. The canvas belongs "to the branch of pure decoration" and the "main design [...] is one of great beauty"; he praises the figures, whose "faultlessly beautiful heads, painted in a delicate half-shadow, [bear] each to the other two a singularly harmonious relation". As for the snake, it appears in "more than one classic bas-relief" and is "more pictorial" than "the more orthodox dragon". But he establishes a telling analogy between the "central nymph [...] amorously encircled by a huge python" and "Gustave Flaubert's Salammbô". Furthermore, he articulates his unease about the treatment of the "crumpled, intricate folds of the many-coloured draperies", which he deems exaggerated and "very insufficiently accounted for by the forms and surfaces which they cover, and should suggest". To him, "their arbitrary employment in this fashion lends [...] a sort of superficial classicality to the design" which, consequently, he believes is not "Greek" at all (Phillips May 7, 1892, 450). In another review written for the Art Journal, he again evokes the "great guardian python amorously enlacing in its huge folds the nymph", but then estimates that "all these lovely draperies, with their myriad fine folds derived from Greek sculpture and Greek vase painting, are most insufficiently accounted by the forms which they cover, and are primarily intended to express"; Leighton has misused the antique sculptural technique of the "wetted draperies", which should be "cunningly arranged on the naked human form" but are here "quite arbitrary in arrangement" (Phillips 1892, 188). Phillips is in fact touching on Leighton's characteristic treatment of draperies as exterior signs of inner drives and emotions. But other critics visibly enjoyed such suggestive treatment. In the Athenaeum, for example, F.G. Stephens notes that the "damsels [...] are delightfully attired in semidiaphanous robes" and "recline in graceful attitudes", and "the atmosphere [...], in keeping with the subject, is pure and bright"; the fact that he finds that "the lines of the 
limbs of the Hesperides, in their flowing completeness and elegance, harmonize with the folds of the snake's body" (Stephens 1892, 569) shows that the reference to Leighton's noble intentions and pure treatment is a way for him to legitimate a tantalizing image.

The Victorian "classical" paintings of Greek myths no longer complied with the academic precepts that mythological paintings should be elevating and noble, despite the idealizing rhetoric of these artists and their approving critics. Rather, what characterizes the illustrations of the myth of the golden apples studied here is a gendered and clichéd representation of the sexes, or one that reflects contemporary interrogations about the psyche as well as about the body and its drives. In art history, the myth has often allowed artists and writers to tackle the question of desire and the issue of the relationship between the sexes. In the case of these late-Victorian paintings, it gives way to fantasied images of women devised by male artists-erotic representations of female desire which largely revolve around the eroticized symbolism of these fruits. The golden apples evoke lushness and desire; they conflate the mythological theme of sensual bliss and the Biblical symbol of the forbidden fruit of sexual knowledge. They articulate tensions between the mythical and the contemporary, between the legendary and the gendered, between the idealistic and the fantasied. For like other myths and motifs inspired, among other sources, from the classical tradition, they are iconographical pretexts for images of melancholy, self-absorbed or objectified female figures. They tell of contemporary male desires for and anxieties towards the female body, which becomes the site of both expressed and repressed "movements" offered to a male voyeuristic contemplation.

\section{BIBLIOGRAPHY}

[Anon.]. The Times 30 (April 1892): 14.

Barrow, Rosemary. "Drapery, Sculpture and the Praxitelean Ideal”. Frederic Leighton, Antiquity, Renaissance, Modernity. T. Barringer \& E. Prettejohn (eds.). Yale UP, New Haven \& London, 1999, 49-65.

Barrow, Rosemary. The Use of Classical Art and Literature by Victorian Painters, 1860-1912. Lewiston, Queenston and Lampeter: The Edwin Mellen Press, 2007.

Bell, Malcolm. Drawings of Sir J.E. Poynter (not paginated). London: Newnes, 1907.

Blackburn, Henry. Academy Notes. London: Chatto and Windus, 1875-1884.

Carr, J. Comyns. Some Eminent Victorians: Personal Recollections in the World of Art and Letters. London: Duckworth, 1908.

Christian, John. Victorian Dreamers: Masterpieces of Neo-Classical and Aesthetic Movements in Britain. Exhibition catalogue. Tokyo: The Tokyo Shimbun, 1989.

Didi-Huberman, Georges. Devant l'image: questions posées aux fins d'une histoire de l'art. Paris: Éditions de Minuit, 1990.

Didi-Huberman, Georges. Ouvrir Vénus: Nudité, rêve, cruauté. Paris: Gallimard, 2002. 
Didi-Huberman, Georges. L'Image ouverte: motif de l'incarnation dans les arts visuels. Paris: Gallimard, 2007.

Dijkstra, Bram. Idols of Perversity: Fantasies of Feminine Evil in Fin-de-Siècle Culture. Oxford: OUP, 1986.

Gillard-Estrada, Anne-Florence. "Beneath the Surface: Sleeping Beauties in Representations of Antiquity and their Reception (1860-1900)". Sleeping Beauties in Victorian Britain: Cultural, Literary and Artistic Explorations of a Myth. Béatrice Laurent (ed.). Bern and Oxford: Peter Lang, 2014, 213-236.

Jones, S., Newall, C., Ormond, L., Ormond, R., \& Read, B. (eds.). Frederic Leighton 1830-1896. Exhibition Catalogue. London: Royal Academy of Arts/Harry N. Abrams, 1996.

Kestner, Joseph A. Masculinities in Victorian Painting. Aldershot: Scolar Press, 1995.

Kestner, Joseph A. Mythology and Misogyny: The Social Discourse of Nineteenth Century British ClassicalSubject Painting, Wisconsin: U of Wisconsin P, 1999.

Moore, George. "The Royal Academy”. Fortnightly Review 57 (June 1892): 828-839.

Newall, Christopher. The Art of Leighton. London: Phaidon, 1990.

Oliphant, Margaret. “The Royal Academy”. Blackwood's Edinburgh Magazine 119 (June 1876):

753-769.

Phillips, Claude. “The Royal Academy I”. Academy 41 (May 7, 1892): 450-451.

Phillips, Claude. "The Summer Exhibitions at Home and Abroad. I. The Academy and the New Gallery". Art Journal 12 (1892): 187-192.

Prettejohn, Elizabeth. Art for Art's Sake: Aestheticism in Victorian Painting. New Haven; London: Yale UP, 2007.

Prettejohn, Elizabeth. “Aestheticising History Painting”. Frederic Leighton, Antiquity, Renaissance, Modernity. Tim Barringer \& Elizabeth Prettejohn (eds.). New Haven; London: Yale UP, 1999, 89-110.

Quilter, Harry. “French and English pictures”. Cornhill Magazine 40 (July 1879): 92-106.

Ormond, Leonée \& Richard. Lord Leighton. New Haven; London: Yale UP, 1975.

[Stephens, F.G.]. “Royal Academy (First Notice)”. Athenaeum 2270 (April 29, 1871): 531-533.

[Stephens, F.G.]. “The Royal Academy (First Notice)”. The Athenaeum 3366 (April 30, 1892): 569-574.

Warburg, Aby. "La Naissance de Vénus et Le Printemps de Sandro Botticelli”. Essais Florentins. Paris: Klincksiek, 1990.

Wood, Christopher. Olympian Dreamers: Victorian Classical Painters 1860-1914. London: Constable, 1983.

\section{NOTES}

1. The painters concerned are Frederic Leighton, Edward Poynter, William Blake Richmond, Albert Moore, Lawrence Alma-Tadema and their followers. Christopher Wood calls them "neoclassical", "classical", "Parnassian" or "Olympian" painters (Wood 15-32; 156-191). In her 
synthetic study, Rosemary Barrow refers to the uses of Greek and Roman visual and literary sources in Victorian painting (2007).

2. Elizabeth Prettejohn employs the term "Art for Art's Sake" rather than "Aestheticism"; the painters she associates with that movement are D.G. Rossetti, Albert Moore, Frederic Leighton, Simeon Solomon or James Abbott McNeill Whistler (Prettejohn 2007, 101-162; 233-254).

3. In J. Solomon's The Judgment of Paris (1896), for instance, the apple has the same shape as the breast of the nude Aphrodite.

4. Edward John Poynter, Atalanta's Race (1876), oil on canvas, dimensions unknown, formally in the Wortley Hall, South Yorkshire, then destroyed during World War II.

5. A photograph credited to the Christopher Wood Gallery is reproduced in Kestner 1989, 251 and 1995, 276.

6. One engraving by Joubert was sold at an auction: https:// www.liveauctioneers.com/ item/6258423_atalantas-race-engraving-by-joubert (all online links accessed Feb. 2016). A Minton pottery plaque after the painting was sold at Sotheby's in 1991: http:// www.liveauctioneers.com/item/20485990_a-minton-pottery-plaque-after-sir-edward-johnpoynter.

7. See online: https://archive.org/details/drawingsofsirejp00bell. See also Edward Poynter, Study for Atalanta's Race, drawing (c. 1876), Victoria \& Albert Museum: http:// conventiculum.wikispaces.umb.edu/file/view/Poynter\%20Atalanta\%20image.jpg/353480326/ Poynter\%20Atalanta\%20image.jpg.

8. Atalanta's name is derived from the Greek "equal in weight". The story of the race is mentioned in Catalogues of Women, fragment 14b-c, by Hesiod (c. 750 BC); the Bibliotheca (Book 3 , chapter 9, section 2) by Pseudo-Apollodorus; the Idylls (3, 40ff) of Theocritus (c. 315-250); the Fabulae (185) by Hyginus (c. $64 \mathrm{BC}-17 \mathrm{AD})$; and the Metamorphoses $(10,560 \mathrm{ff})$ and History of Love (6.1 ff) by Ovid (43 BC-17 AD).

9. A black-figured hydria of c. 550 represents her manfully wrestling with Peleus (Staatliche Antikensammlungen, Münich).

10. The Barberini Atalanta, a Greek marble of the $1^{\text {st }}$ century BC (Vatican Museums), is a standing woman-hunter.

11. For Kestner the painting relocates the free woman within her allotted place in society (Kestner 1995, 242-243).

12. There are two versions of Atalanta and Hippomenes (oil on canvas): one at the Museo Nacional del Prado, Madrid (c. 1615-1618), and the other at the Museo di Capodimonte, Naples (c. 1620).

13. George Du Maurier, "Pictures of the Day to Come. II. Doctor Meilanion Jones, finding himself outstripped in the race for patients by the fair Doctoress Atalanta Robinson, gallantly throws her a wedding ring, and wins the day," Punch 1877: http://punch.photoshelter.com/image/ I0000LfRTktFxSfo.

14. Nikai leading a bull to sacrifice (c. $410 \mathrm{BC}$ ), marble statues, Acropolis Museum, Athens; there are Roman marble copies in Florence (Uffizi).

15. Xanthos, Nereid Monument, fourth century BC, British Museum

16. For instance, the figures on the right in Botticelli' Birth of Venus (1485, Uffizi, Florence) and in Domenico Ghirlandaio's Birth of the Baptist (1486-1490, Santa Maria Novella, Florence).

17. John Christian believes this unlikely on the ground that Reni is not usually associated with Leighton and was generally out of favour at that time (Christian 110); yet for the Ormonds, Leighton would have known Reni's work (Ormond 1975 61ff).

18. Joshua Reynolds (1723-1792), Three Ladies Adorning a Term of Hymen (1773), oil on canvas, $233.5 \times 290.8 \mathrm{~cm}$, Tate Britain.

19. The story of the apple-tree of the Hesperides is mentioned in Pseudo-Apollodorus's Bibliotheca (Book 2, chapter 113, section 4) and in Pseudo-Hyginus's Astronomica (Book 2, 3). 
20. Edward Burne-Jones, The Garden of the Hesperides, c. 1870, gouache on paper, 119x98cm, Kunsthalle, Hamburg.

21. Frederic Leighton, Flaming June (1895), oil on canvas, Museo de Arte de Ponce, Puerto Rico, $120.6 \times 120.6 \mathrm{~cm}$. The woman depicted wears the same red-orange drapery as the Hesperide playing the lyre.

22. This figure is also part of an iconographical network, as she is modelled on Michelangelo's painting Leda and the Swan (destroyed) and his sculpture of Leda (San Lorenzo Church, Florence), which Peter Paul Rubens copied in his Leda with Swan (1530, National Gallery); then, Leighton inspired Gustav Klimt's Danaë (1907, Galerie Würthle, Vienna) (Gillard-Estrada 223-226).

23. For Wood, "the mood is one of passive nostalgia and yearning for a lost world of classical beauty and order" (Wood 54).

24. L. Ormond mentions that it is derived from a Greco-Roman bas-relief reproduced in C. Daremberg and E. Saglio's Dictionnaire des antiquités grecques et romaines of 1877 (Jones 232-3).

25. Revealingly, F.F. Coppola placed Leighton's canvas in Lucy's manor in his 1992 film Bram Stoker's Dracula, which among other themes stresses lesbianism and female autoeroticism.

\section{ABSTRACTS}

This article studies a number of Victorian paintings that represented Greek myths of the golden apples. These artworks - often identified as "classical" by contemporary art critics but also categorized as "Aesthetic" - articulate gendered tensions, fantasies and anxieties. In particular, this article explores representations of the myths of Atalanta's race and of the garden of the Hesperides. Close attention is paid to the images themselves thanks to a reading that is informed by the works of French art historian Georges Didi-Huberman. Studying the critical reception of such works in contemporary journalistic reviews also allows to uncover ambivalent approaches to the emotional charge of these works. For beyond academic conventions and formal Aesthetic concerns, what is at stake in these representations of the myths of the golden apples is the significance of the body and its desires.

Cet article se propose d'étudier un certain nombre de tableaux de l'époque victorienne qui traitent de mythes grecs des pommes d'or. Ces œuvres, souvent considérées par la critique d'art de l'époque comme appartenant à l'école «classique » mais situées aussi dans le Mouvement Esthétique, articulent des tensions, des fantasmes et des angoisses contemporaines liées notamment aux représentations des genres. Cette étude s'intéresse particulièrement au traitement du mythe d'Atalante et du Jardin des Hespérides. Ces œuvres sont abordées par le biais des travaux sur les images de Georges Didi-Huberman ainsi qu'à travers la réception critique parfois ambivalente d'œuvres qui contiennent une charge émotionnelle forte, dans les périodiques contemporains. Au-delà des conventions académiques et des préoccupations formelles propres à l'Esthétisme, ce qui se joue dans ces variations sur les pommes d'or est le rôle du corps et de ses désirs. 


\section{INDEX}

oeuvrecitee Atalanta's Race, Garden of the Hesperides (The), Atalanta in Calydon, Atalanta's Defeat

Mots-clés: mythologie grecque, peinture victorienne, académisme, esthétisme, formes plastiques, forme humaine

Keywords: Greek mythology, Victorian painting, academicism, aestheticism, plastic forms, human form

\section{AUTHORS}

\section{ANNE-FLORENCE GILLARD-ESTRADA}

Anne-Florence Gillard-Estrada is a lecturer at Rouen University. Her research and teaching interests include British literature, art criticism and painting of the 1860s-1890s. She has published a number of articles on Walter Pater, Oscar Wilde, and "classical" and "Aesthetic" painting. She is currently writing a book on the subject of "Greece" and the body in British paintings of Antiquity (1860-1900) that draws on close readings of the images through the theoretical approaches of French art historians such as Georges Didi-Huberman as well as on the reception of these works in Victorian art criticism and periodicals. 